\title{
Physicochemical and microbiological quality of raspberries (Rubus idaeus) treated with different doses of gamma irradiation
}

Isabela Costa GUIMARÃES ${ }^{1,2 *}$, Evandro Galvão Tavares MENEZES ${ }^{1,2}$, Priscilla Silva de ABREU ${ }^{1,2}$, Ariel Costa RODRIGUES ${ }^{1,2}$, Paulo Rogério Siriano BORGES ${ }^{1,2}$, Luis Roberto BATISTA ${ }^{1,2}$, Marcelo Angelo CIRILO ${ }^{1,2}$, Luiz Carlos de Oliveira LIMA ${ }^{1,2}$

\begin{abstract}
This study was conducted to evaluate the physicochemical and microbiological characteristics of raspberries exposed to different radiation doses. The fruits were harvested in the city of Campestre, MG, packed in polyethylene bags, and transported to the Federal University of Lavras (UFLA), where they were separated into 4 lots. Irradiation was performed at the Center for Development of Nuclear Technology in Belo Horizonte, MG. The doses used were 0 (control), 0.5, 1.0, and $2.0 \mathrm{kGy}$. After irradiation, the fruits were transported back to UFLA and stored at $1{ }^{\circ} \mathrm{C}$ and $95 \%$ relative humidity (RH) for 12 days. The physicochemical analyses for mass loss, total soluble solids, titratable acidity, $\mathrm{pH}$, total soluble sugars, total soluble pectin, firmness, vitamin $\mathrm{C}$ content, total antioxidant activity, and total phenolic, and the microbiological assays (coliform at 35 and $45^{\circ} \mathrm{C}$, psychrotrophic and filamentous fungi and yeasts) were performed after $0,3,6,9$, and 12 days of storage. Lower loss of mass and filamentous fungi and yeast count were observed in the irradiated fruits, and $2 \mathrm{kGy}$ was determined as the most effective dose for microbial control, but this irradiation dose also resulted in increased loss of fruit firmness.
\end{abstract}

Keywords: $\mathrm{Co}^{60}$ radiation; postharvest; conservation.

\section{Introduction}

Quality attributes generally considered by consumers in their selection and purchase of most fruits include: appearance, taste, smell, nutritional value, and absence of defects. In the case of raspberries, this condition is not difficult to achieve because this fruit presents a peculiar attraction due to its color (red, black, and yellow), pleasant odor, soft texture, and slightly sour flavor.

The wide acceptability of raspberry is related not only to its sensory characteristics, but also to its chemical composition since it is rich in antioxidant substances such as vitamin C, carotenoids, and phenolic compounds thus rendering it a very healthy fruit. It is also a source of carbohydrates, minerals, and other vitamins and it has low calorie and fat content, while being rich in soluble fiber (BEATTIE; CROZIER; DUTHIE, 2005; PANTELIDIS et al., 2007; PLESSI; BERTELLI; ALBASINI, 2007; TALCOTT, 2007). Raspberries are extremely sensitive to handling and fungal attack, and thus it requires careful handling, harvesting, storage, and transportation; therefore, postharvest cleaning, such as washing or sanitizing, is strongly discouraged.

Irradiation is a common physical process that destroys pathogenic microorganisms and those that cause food spoilage. It is also used to eliminate insects and retard the germination process in plant products. Therefore, irradiation increases food safety and reduces losses caused by deterioration (RESURRECCION et al., 1995). Irradiation has been studied for several years and since 1963, the Food and Drug Administration (FDA) has regulated the use of radiation in wheat and wheat flour processing for human consumption. Application of radiation has also been guided by Good Manufacturing Practices (GMP's) (LAGUNAS-SOLAR, 1995). By the 1980s and 1990s, new regulations emerged with the aim of extending this technology to other foods (ORNELLAS et al., 2006).

Fruit irradiation has been used by countries such as Thailand and India to compete against the Brazilian fruit export, especially after restrictions have been imposed on more common quarantine treatments such as fumigation using methyl bromide or oxide ethylene and submergence in hot water. In order to achieve effective treatments, harvesting should be done before the fruit's optimal maturation period, which otherwise would damage the fruit's flavor and sensory characteristics. Irradiation imparts minimal effect on the chemical and sensory characteristics of food, when the established maximum dose for each product is used. The irradiation process, when properly conducted, does not cause damages to the environment or to human health, and thus it is fully supported by international institutions such as the World Health Organization (WHO), Food and Agricultural Organization (FAO), FDA, and National Health Surveillance Agency (ANVISA). The use of irradiation has also been strongly based on several studies that have confirmed its safety and effectiveness (PEROZZI, 2007).

One major advantage offered by irradiation is that it requires a minimal handling of the food item, thus enabling decontamination without inducing any mechanical damage; it also reduces the time it takes for the product to reach consumers.

${ }^{1}$ Departament of Food Science, University Federal of Lavras - UFLA, CP 3037, CEP 37200-000, Lavras, MG, Brazil, e-mail: icostag@yahoo.com.br

${ }^{2}$ Center for Development of Nuclear Technology, Federal University of Minas Gerais - UFMG, Belo Horizonte, MG, Brazil

${ }^{*}$ Corresponding author 
The objective of this study was to evaluate the physicochemical and microbiological effects of irradiating raspberries with different doses of Cobalt-60 gamma and storing at $1{ }^{\circ} \mathrm{C}$ and $95 \%$ relative humidity $(\mathrm{RH})$, thus creating an alternative approach to postharvest processing that conserves the natural characteristics of the fruit and possibly extends its shelf-life.

\section{Materials and methods}

\subsection{Vegetable material}

Raspberries (Rubus idaeus), cultivar "autumn bliss", were harvested from a Campestre- plantation, MG-Brazil. The selection criteria for the fruits included: acceptable and attractive appearance, physiological maturity based on size and color, and absence of injuries related to handling and/or diseases. The crop was harvested in December 2011 in the cool morning hours to minimize moisture loss by transpiration. The fruits were harvested manually, stored in polyethylene trays (approximately 100 grams of fruit per tray), and packed in 20-L styrofoam boxes packed with ice to remove field heat and to refrigerate the fruits during transport to the Laboratory of Postharvest Fruit and Vegetable, Department of Food Science, Federal University of Lavras (UFLA).

\subsection{Gamma irradiation}

Irradiation was performed one day after harvest (approximately 24 hours after collection). Raspberry samples were transported in refrigerated styrofoam boxes to the Gamma Radiation Laboratory (LIG) of the Center for Development of Nuclear Technology, Federal University of Minas Gerais (UFMG), where they were irradiated in a Gammacell-127 GB, IR-214 panoramic irradiator (MDS Nordion, Canada) with Cobalt-60 source. The fruits were placed on a turntable that was positioned around the Co-60 source. It was not necessary to remove the raspberries from its packaging or boxes because radiation can traverse the physical barrier. The doses used for the treatment were 0 (control), $0.5,1.0$, and $2.0 \mathrm{kGy}$. After the treatment, the fruits were transported back to the UFLA and stored at $1{ }^{\circ} \mathrm{C}$ and $95 \% \mathrm{RH}$ and analyzed at different storage times $(0,3,6,9$, and 12 days).

\subsection{Physicochemical analysis}

Fruit weight loss (W. loss) was calculated as the percentage difference between the initial weight of the fruit upon storage and the final weight of the fruits after a specific number of days of storage. The fruits were weighed in a semi-analytical balance.

The Total Soluble solids (SS) were measured using a digital refractometer (ATAGO PR-100) equipped with automatic temperature compensation at $25^{\circ} \mathrm{C}$ (ASSOCIATION..., 2000); the total amount of SS was measured as Brix content of SS.

The level of acidity (Titratable acidity -TA) in the fruits was determined by titration with $0.1 \mathrm{~N} \mathrm{NaOH}$ and a phenolphthalein indicator, according to AOAC (ASSOCIATION..., 2000) and expressed as \% citric acid.
The $\mathrm{pH}$ level of the fruits was determined following the potentiometric method using a digital potentiometer $/ \mathrm{pH}$ meter TECNAL (Tec 3MP), according to AOAC (ASSOCIATION..., 2000).

The total amount of soluble sugar (TSS) in the fruits was determined by extraction using ethanol $95 \%(\mathrm{v} / \mathrm{v})$ using the Anthrone method (DISHE, 1962). The results were expressed in grams of glucose per $100 \mathrm{~g}$ of fruit.

The technique of McCready and McComb (1952) was used for the extraction of pectin from the fruits. The total amount of pectin (TP), soluble pectin (SP), and solubility was determined colorimetrically following the study by Bitter and Muir (1962). The measurements were expressed as $\mathrm{mg}$ of galacturonic acid per 100 grams of fruit. The percentage of solubility was calculated from the ratio of soluble pectin to total pectin (SP/TP).

Firmness was measured using a texturometer TA-XT2i Texture Analyzer equipped with a needle probe. Ten fruits were randomly selected and texture was measured at 2 different points in each fruit (top and bottom). The measurements were expressed as force $(\mathrm{N})$ used by the probe to penetrate the fruit to a depth of approximately $3 \mathrm{~mm}$.

Total amount of ascorbic acid was colorimetrically determined according to the method by Strohecker and Henning (1967) using 2,4-dinitrophenylhydrazine. The results were expressed as $\mathrm{mg}$ of ascorbic acid per $100 \mathrm{~g}$ of fruit.

The antioxidant compounds were extracted using the methodology described Rufino et al. (2007). The methodology used to determine total antioxidant activity (TAA) was based on the absorption of $60 \mathrm{mM} \mathrm{2,2-diphenyl-1-picryl}$ hydrazyl (DPPH), as described by Rufino et al. (2007), with some adjustments in the calculation procedure, in which the percentage of the sequestered free radical DPPH was used as the standard. The readings were taken after 30 min using a spectrophotometer at an absorbance wavelength of $515 \mathrm{~nm}$, and the results were expressed as percentage of sequestered free radical (\%SFR) using the following Equation 1 :

$\% \mathrm{SFR}=\frac{((\text { Absorbance of control }- \text { absorbance of sample }) \times 100)}{\text { Absorbance of control }}$

For the determination and quantification of phenolic compounds, the colorimetric method developed by Waterhouse (2002) was used with $10 \%$ Folin-Ciocalteu reagent. To calculate the total phenolic content, a standard curve using gallic acid solution was constructed. The results were expressed as gallic acid equivalents (grams of GAE per grams of fruit).

\subsection{Microbiological analysis}

Microbiological analysis was performed in triplicate using 3 dilutions $\left(10^{-1}, 10^{-2}\right.$, and $\left.10^{-3}\right)$. A sample of approximately $25 \mathrm{~g}$ was aseptically collected and transferred to a shaker with $225 \mathrm{ml}$ of sterile $0.1 \%$ peptone water. From this stock solution, serial dilutions were prepared in tubes containing $9 \mathrm{ml}$ of $0.1 \%$ peptone water using the technique described by Silva et al. (2007). 
For determination of Coliform bacteria at 35 and $45{ }^{\circ} \mathrm{C}$ (thermotolerant), the protocol of Silva et al. (2007) was followed using lauryl sulfate tryptose (LST) broth and incubating at $35^{\circ} \mathrm{C}$ for detection of total coliform and $45^{\circ} \mathrm{C}$ for fecal coliform.

To detect the presence of yeast and mold (Filamentous fungi), each extract was inoculated on dichloran chloramphenicol rose bengal (DRBC) agar plates (SILVA et al., 2007).

For psychrotrophic aerobic counts, each extract was inoculated on plate count agar (PCA), as described by Silva et al. (2007).

\subsection{Statistical analysis}

All data were analyzed using analysis of variance (ANOVA) and when the isolated factors or their interactions were determined to be significant, regression coefficients and the Tukey test were calculated at a 5\% significance level using a completely randomized design (CRD) in a $4 \times 5$ factorial (4 doses of irradiation, 5 days of storage) with 3 replicates; the plot consisted of a tray (approximately $100 \mathrm{~g}$ ) of fresh raspberries, and by using MINITAB 16. A significant interaction was detected, in which a split in the doses in each storage time was observed.

\section{Results and discussion}

Adopting a significance level of $5 \%$, it can be said that there was significant interaction between doses of irradiation and storage time for the variables weight loss, firmness, ascorbic acid, total antioxidant activity, total phenolic content and filamentous fungi and yeasts. For the variables titratable acidity, soluble pectin, and solubility, only the storage time was significant, and for soluble sugars there was no significant effect of storage time and irradiation doses separately. There was no significant effect of any of the sources of variation for soluble solids (Table 1).

With regards to the weight loss (Figure 1), there was an increase over time, and the higher the irradiation dose ( $2 \mathrm{kGy}$ ), the lesser the weight loss.

Weight loss is one of the physiological parameters used as quality indicator in fruits. Fruits and vegetables, even when kept under ideal conditions, generally undergo a decrease in mass during storage based on the combined effect of respiration and transpiration (CHITARRA; CHITARRA, 2005). Maxie,
Sommer and Mitchell (1971) reported that irradiation increased membrane permeability, transpiration, and metabolic activity, and it disrupted intercellular connections. However, other researchers argued that by using an optimal dose of irradiation, the shelf life of fruits and vegetables could be extended (ARTESHERNANDEZ et al., 2010; LÓPEZ-RUBIRA et al., 2005). Oliveira et al. (2006) showed that the application of $600 \mathrm{~Gy}$ gamma irradiation on postharvest of guava fruits resulted in a lower mass loss as compared to non-irradiated fruits (control) and fruits irradiated with 300 and $900 \mathrm{~Gy}$, which showed the largest loss.

The lower increase in weight loss in irradiated samples during storage could be probably attributed to the modifications caused in cellular integrity and pore size due to the radiation treatment, thereby affecting moisture loss to the atmosphere (RASTOGI et al., 2006; RASTOGI, 2005; HAYASHI; TODORIKI; NAGAO, 1992).

For the variable total soluble sugars (TSS), a tendency to increase over time was observed without interacting with the irradiation doses applied (Figure 2). The lowest TSS value in the non-irradiated fruits was observed in the average TSS value of the treatments, and higher or similar TSS values were observed in the fruits irradiated with doses of $0.5,1$ and $2 \mathrm{kGy}$ (Table 2). The change in sugar content during storage is related to the sensory characteristics of fruits and their conservation potential,

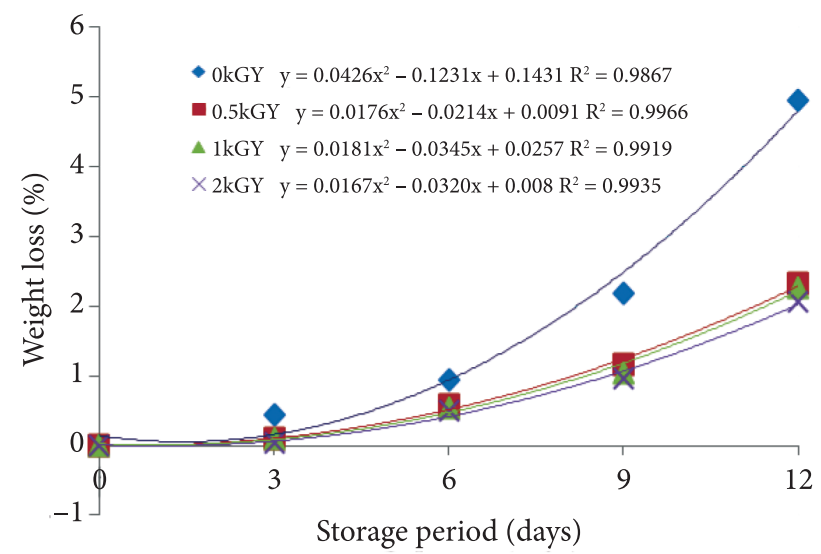

Figure 1. Weight loss during cold storage of raspberries exposed to different irradiation doses $(0,0.5,1.0$, and $2.0 \mathrm{kGy})$.

Table 1. Statistical significance for the response variables as a function of the major effects and interaction.

\begin{tabular}{|c|c|c|c|c|c|c|c|}
\hline \multirow{2}{*}{ SV } & \multirow{2}{*}{ DF } & \multicolumn{6}{|c|}{$\mathrm{p}$-value } \\
\hline & & TA & $\mathrm{pH}$ & SS & TSS & Firmness & $\mathrm{SP}$ \\
\hline Treatment $(\mathrm{T})$ & 3 & 0,539 & 0,056 & 0,934 & $0,036^{*}$ & $0,000^{*}$ & 0,554 \\
\hline Time (t) & 4 & $0,000^{*}$ & $0,003^{*}$ & 0,410 & $0,000^{*}$ & $0,000^{\star}$ & $0,000^{\star}$ \\
\hline Txt interaction & 12 & 0,269 & 0,118 & 0,196 & 0,114 & $0,000^{*}$ & 0,874 \\
\hline \multirow{2}{*}{ SV } & \multirow{2}{*}{$\mathrm{DF}$} & \multicolumn{6}{|c|}{ p-value } \\
\hline & & Solubility & $\%$ SFR & Vit C & Phenolic & W. loss & Fungi \\
\hline Treatment (T) & 3 & 0,273 & $0,000^{*}$ & $0,001^{*}$ & $0,000^{*}$ & $0,000^{*}$ & $0,000^{*}$ \\
\hline Time (t) & 4 & $0,000^{*}$ & $0,000^{*}$ & $0,000^{*}$ & $0,000^{*}$ & $0,000^{*}$ & $0,000^{*}$ \\
\hline Txt interaction & 12 & 0,096 & $0,000^{*}$ & $0,000^{\star}$ & $0,000^{*}$ & $0,000^{*}$ & $0,000^{*}$ \\
\hline
\end{tabular}

${ }^{*}$ Probability $(p$-value $<0.05$ ) indicates significant effects. 
as well as reserve substances (CHITARRA; CHITARRA, 2005; EPRILIATI et al., 2010).

The $\mathrm{pH}$ and titratable acidity were significantly affected by the time of storage, during which an increase in $\mathrm{pH}$ values and consequent decrease in acidity were observed (Figure 3 ). The organic acids, together with the sugar content, comprise an important quality attribute in fruits. Many of these acids are volatile contributing significantly to the characteristic flavor of each fruit (KLUGE et al., 2002). Françoso et al. (2008) reported that the $\mathrm{pH}$ and acidity of strawberries treated with different doses of Co-60 gamma irradiation and stored for 29 days were significantly affected only by storage time, during which an increase in $\mathrm{pH}$ and a decrease in acidity were observed.

The decrease in acidity can be attributed to the use of organic acids as respiratory substrates and as carbon skeleton for the synthesis of new compounds during ripening (FAN et al., 2009).

Regarding the variable firmness, it was observed a negative effect of irradiation dose since in general all treatments showed a reduction over time, while the treatment with the highest dose $(2.0 \mathrm{kGy})$ resulted in lower firmness at the end of the storage period (Figure 4). Soluble pectin content and solubility increased during storage (Figures 5 and 6 ).

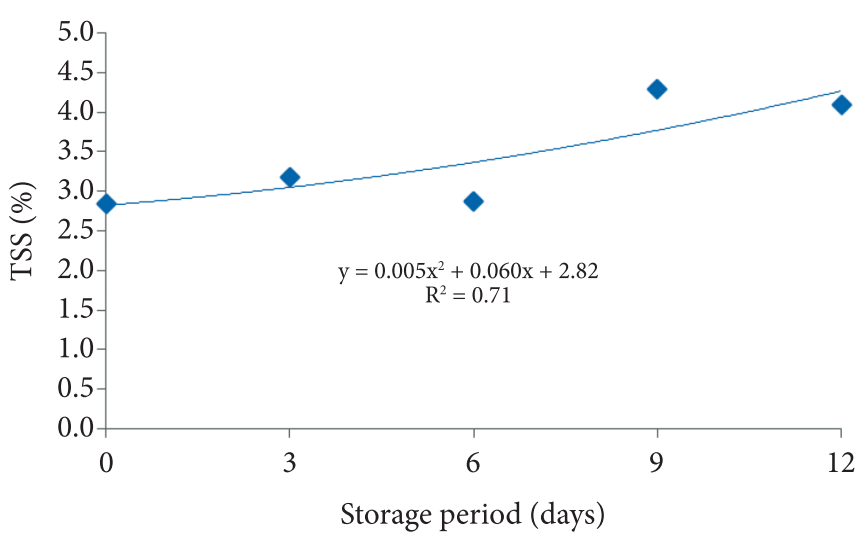

Figure 2. Total soluble sugar content during cold storage of raspberries exposed to different irradiation doses $(0,0.5,1.0$, and $2.0 \mathrm{kGy})$.

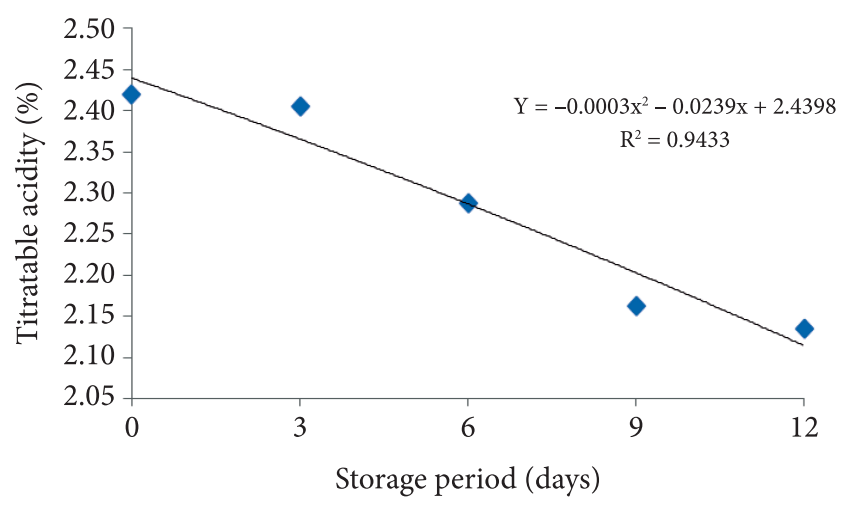

Figure 3. Titratable acidity during cold storage of raspberries exposed to different irradiation doses $(0,0.5,1.0$, and $2.0 \mathrm{kGy})$.
Table 2. Mean values of total soluble sugar content of raspberries during storage and after exposure to different irradiation doses $(0$, $0.5,1.0$, and $2.0 \mathrm{kGy}$ ).

\begin{tabular}{cc}
\hline Irradiation Dose coluna (kGy) & TSS (\%) \\
\hline 0 & $3,14^{\mathrm{b}}$ \\
0,5 & $3,41^{\mathrm{ab}}$ \\
1 & $3,72^{\mathrm{a}}$ \\
2 & $3,54^{\mathrm{ab}}$ \\
\hline
\end{tabular}

Means followed by the same letter do not differ among themselves by Tukey test at $5 \%$ probability.

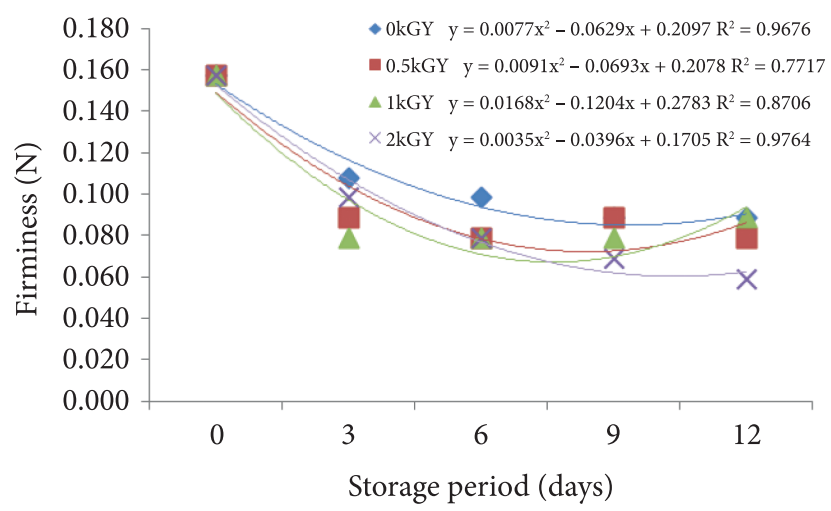

Figure 4. Changes in firmness during cold storage of raspberries exposed to different irradiation doses (0, 0.5, 1.0, and $2.0 \mathrm{kGy})$.

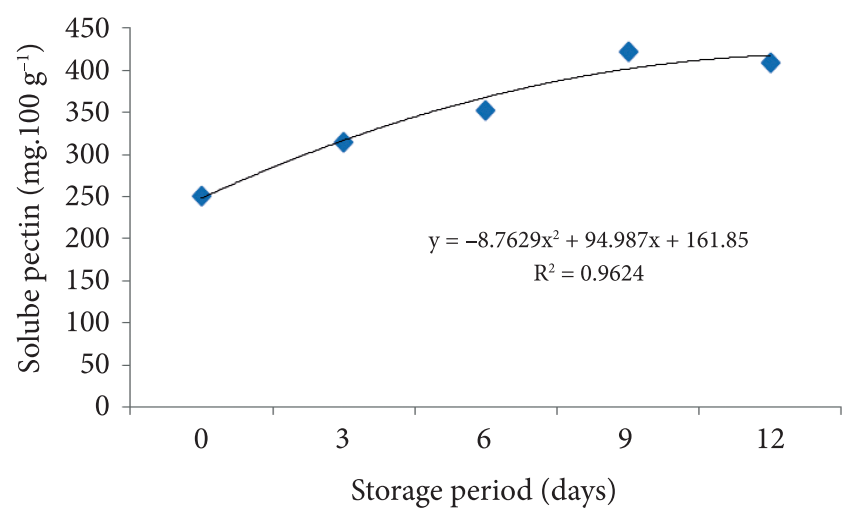

Figure 5. Changes in soluble pectin content during cold storage of raspberries exposed to different irradiation doses $(0,0.5,1.0$, and $2.0 \mathrm{kGy})$.

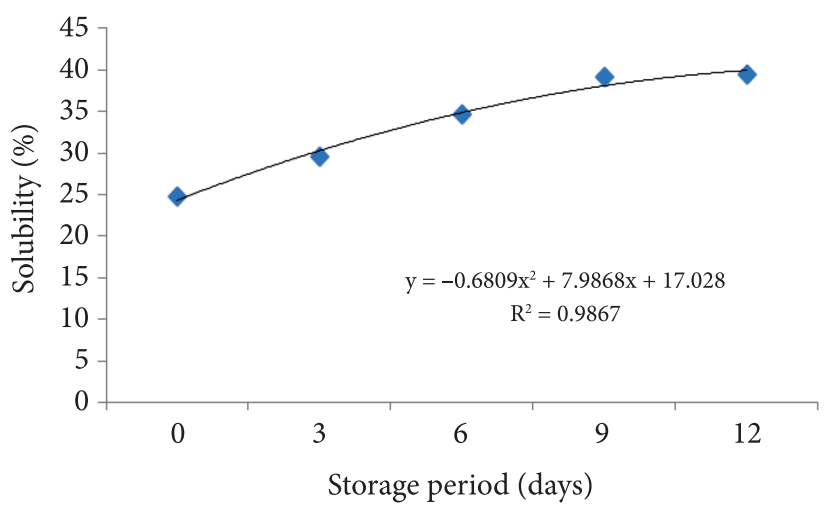

Figure 6. Percentage of solubility during cold storage of raspberries exposed to different irradiation doses (0, 0.5, 1.0, and $2.0 \mathrm{kGy})$. 
Françoso et al. (2008) reported an increase in the amount of soluble pectin and solubility during storage of irradiated strawberries, regardless of the irradiation dose. Pineapple and cashew showed a longer duration of firmness during storage after Co-60 gamma radiation than that of non-irradiated fruits (SILVA; SILVA; SPOTO, 2008; SOUZA et al., 2009). However, Oliveira et al. (2006) showed that guavas irradiated with 600 Gy remained firmer than control guavas irradiated with 300 and $900 \mathrm{~Gy}$. Thus, irradiation can be harmful to the tissue since no adequate doses (higher than that supported by vegetal) can cause cell disruption leading to decrease in firmness; this could be the reason for higher loss of firmness in raspberries radiated with the highest dose (2.0 kGy).

In fruits, the softening of tissue is related to changes in cell wall structure. These changes generally occur due to degradation and solubilization of pectin and the action of enzymes, which result in modification of cell wall structure. The role of protopectinase in the decomposition of macromolecules such as cellulose, hemicellulose, and starch results in the softening of cell walls decreasing the cohesive force that holds cells together thus leading to a decrease in fruit firmness (CHITARRA; CHITARRA, 2005).

For the variable ascorbic acid, a tendency to increase during storage was observed for the doses of 1 and $2 \mathrm{KGy}$, while doses of 0.5 and $0 \mathrm{KGy}$ showed the highest values of ascorbic acid up to 9 days of storage and decreased close to the end of the storage period showing the lowest values (Figure 7). For the variable total phenolic, similar response occurred between the treatments throughout the storage time, except for the dose of 2 $\mathrm{kGy}$, which showed higher values than those of the 9 and 12 days of storage (Figure 8). It was also observed an increase trend for the variable antioxidant activity at a dose of $2 \mathrm{kGy}$ during storage (Figure 9), corresponding to the observed increase in vitamin $\mathrm{C}$ and phenolic compounds, since these two groups of molecules are highly related to in vitro antioxidant activity (RUFINO et al., 2010; YE et al., 2011).

The total antioxidant activity represents the action of various compounds such as phenolic compounds and vitamin C

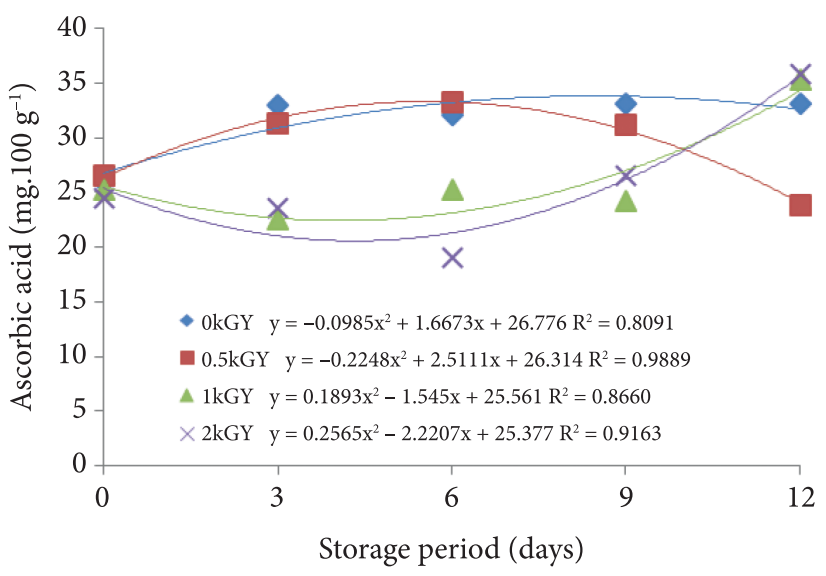

Figure 7. Ascorbic acid levels during cold storage of raspberries exposed to different irradiation doses $(0,0.5,1.0$, and $2.0 \mathrm{kGy})$. (ascorbic acid) to prevent cell oxidation and free radical formation; both of which promote human health. Mechanical damage, decay, and aging promote cell wall disruption releasing degradation enzymes such as polyphenol oxidase and ascorbate oxidase, which are responsible for the oxidation of ascorbic acid (MOKADY; COGAN; LIEBERMAN, 1984). Eichholz et al. (2011) showed that the application of UV-C in blueberries resulted in a higher total phenolic content as compared to control fruits. Sun-dried gamma irradiated apricots showed enhanced capacity to retain high levels of ascorbic acid and antioxidant activity (measured by the method of $\beta$-carotene) as compared to control fruits, and the most effective dose was 2.5-3.0 kGy (HUSSAIN et al., 2011). In kiwi, irradiation with 1 and $2 \mathrm{kGy}$ resulted in a 50\% decrease in ascorbic acid level compared to than that of control fruits $(0 \mathrm{kGy})$ and to that of $0.5 \mathrm{kGy}$-treated fruits (HARDER et al., 2009).

In the case of responses related to filamentous fungi and yeasts (Figure 10), an increasing effect related to time was observed; in other words, there was greater fungal growth over

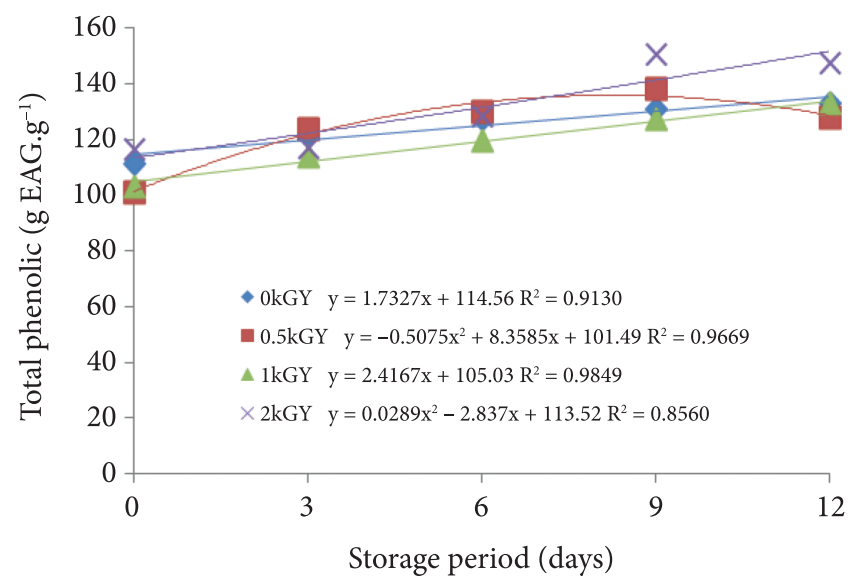

Figure 8. Change in total phenolic content during cold storage of raspberries exposed to different irradiation doses $(0,0.5,1.0$, and $2.0 \mathrm{kGy})$.

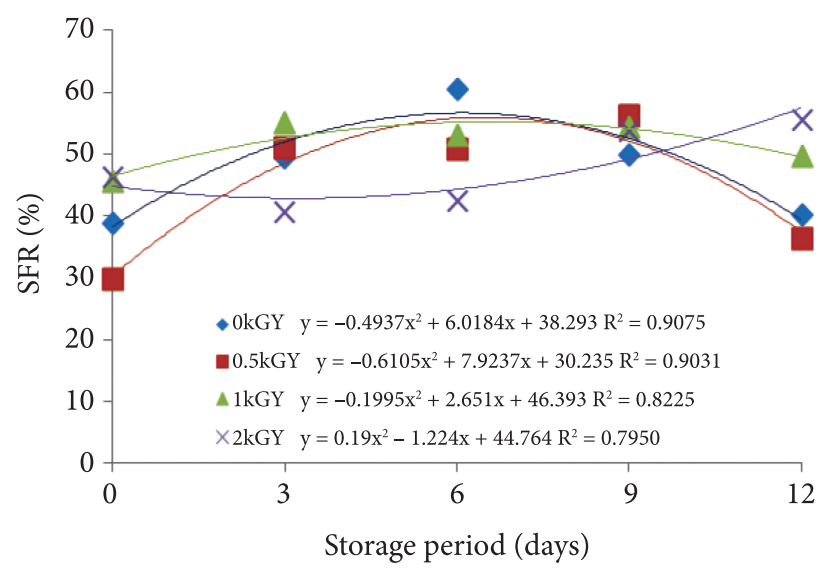

Figure 9. Change in total antioxidant activity (\%SFR) during cold storage of raspberries exposed to different irradiation doses $(0,0.5$, 1.0 , and $2.0 \mathrm{kGy})$. 


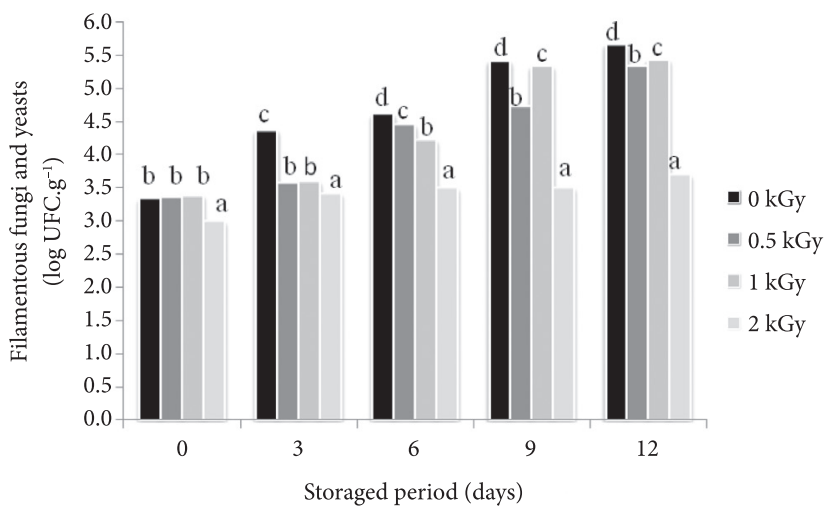

Figure 10. Number of filamentous fungi and yeast in raspberries exposed to different irradiation doses $(0,0.5,1.0$, and $2.0 \mathrm{kGy})$ and stored under refrigeratation. Treatment means followed by the same letter indicate lack of significance for each time interval based on a $5 \%$ significance level by the Tukey test.

time. With respect to the irradiation dose, it can be said that the highest dose resulted in the lowest microbial growth.

Fresh fruits and vegetables are generally considered as carriers of diseases, attributable to the presence of fecal Escherichia coli and Salmonella sp. that are usually present in the irrigation water, manure in the soil or fertilizer, or due to improper handling of the product (GANGLIARDI; KARNS, 2000).

Bacterial coliforms were not detected at 35 and $45^{\circ} \mathrm{C}$ in any of the treated raspberry samples and the controls during the entire storage period. These results indicate adequate sanitaryhygienic conditions during handling, collection, storage, and transport of the fruits. RDC Resolution No. 12, promulgated on January 2, 2001 by ANVISA, Ministry of Health, issued guidelines for fresh, prepared, sterilized, chilled fruits or frozen fruits meant for direct consumption with a maximum allowable microbial level of $5 \times 102 \mathrm{NMP}^{-1}$ (2.7 log cycles) for coliform bacteria at $45^{\circ} \mathrm{C}$ and Salmonella in $25 \mathrm{~g}$ of the product (BRASIL, 2001). Therefore, the results obtained met the standards set by the legislation for coliform bacteria throughout the storage period.

According to Babic and Watada (1996), yeast and mold populations in the range of $10^{3}-10^{4} \mathrm{CFU} \cdot \mathrm{g}^{-1}$ (3-4 log cycles) detected during storage is considered low. Considering this study, a $2 \mathrm{kGy}$ radiation dose should ensure even lower microbial counts in fruits during the 12-day storage period; however, the average microbial content score at the end of the study in fruit radiated at $2 \mathrm{kGy}$ was below 4 log cycles, while the control fruits radiated at 0.5 and $1 \mathrm{kGy}$ showed mean scores of above $4 \log$ cycles.

The total bacterial, fungal, and yeast counts were significantly reduced in Co-60 gamma irradiated lychees stored for 28 days (HAJARE et al., 2010). Irradiation is commonly used in minimally processed fruits and vegetables allowing effective microbial control (ESCALONA et al., 2010; PINTO, 2010; MARTINS et al., 2004, LIMA et al., 2003).

\section{Conclusions}

On the basis of the experimental conditions used in this study, we conclude the following:

- The use of irradiation on postharvest raspberries is a viable technique;

- Irradiation reduces weight loss and filamentous fungi and yeast count;

- The irradiation dose of $2 \mathrm{kGy}$ is highly effective in controlling microbiological growth, but it is also the dose at which the fruits lose most of their quality and firmness; and

- Further studies using doses between 1 and $2 \mathrm{kGy}$ are required to optimize the raspberry preservation by the irradiation method.

\section{Acknowledgements}

The authors are grateful to "Coordenação e Aperfeiçoamento de Pessoal de Nível Superior (Capes)” for the scholarship granted and to Center for Development of Nuclear Technology, Federal University of Minas Gerais (UFMG) for the irradiation of fruits.

\section{References}

ARTES-HERNANDEZ, F. et al. Low UV-C illumination for keeping overall quality of fresh cut watermelon. Postharvest Biology and Technology, v. 55, n. 2, p. 114-120, fev. 2010. http://dx.doi. org/10.1016/j.postharvbio.2009.09.002

ASSOCIATION OF OFFICIAL ANALYTICAL CHEMISTRY - AOAC. Official methods of analysis of the Association of Official Analytical Chemistry. 17. ed. Washington: AOAC, 2000. 1410 p.

BABIC, I.; WATADA, A. E. Microbial population of fresh cut spinsh leaves affected by controlled atmosphere. Postharvest Biology and Technology, v. 9, n. 2, p. 187-193, nov. 1996. http://dx.doi. org/10.1016/S0925-5214(96)00047-6

BEATTIE, J.; CROZIER, A.; DUTHIE, G.G. Potential health benefits of berries. Current Nutrition \& Food Science, v. 1, p. 71-86, 2005. http://dx.doi.org/10.2174/1573401052953294

BITTER, T.; MUIR, H. M. A modified uronic acid carbazole reaction. Analytical Chemistry, v. 34, p. 330-334, 1962.

BRASIL. Ministério da Saúde. Agência Nacional de Vigilância Sanitária. Resolução RDC n 12, de 02 de janeiro de 2001. Aprova o regulamento técnico para misturas para o preparo de alimentos e alimentos prontos para consumo. Diário Oficial da República Federativa do Brasil, Brasília, DF, jan. 2001. Available from: <htpp://www.anvisa.gov.br/legis/resoluções/12_01.htm>. Access in: 12 Nov 2011.

CHITARRA, M. I. F.; CHITARRA, A. B. Pós-colheita de frutos e hortaliças: fisiologia e manuseio. 2. ed. rev. ampl. Lavras: UFLA, 2005. $785 \mathrm{p}$.

DISCHE, Z. General color reactions. In: WHISTLER, R. L.; WOLFRAM, M. L. Carbohydrate chemistry. New York: Academic, 1962. p. 477-512.

EICHHOLZ, I. et al. UV-B-induced changes of volatile metabolites and phenolic compounds in blueberries (Vaccinium corymbosum L.). Food Chemistry, v. 126, p. 60-64, 2011. http://dx.doi.org/10.1016/j. foodchem.2010.10.071

EPRILIATI, I. et al. Chromatographic analysis of diverse fruit components using HPLC and UPLC. Analytical Methods, v. 2, p. 1606-1613, 2010. http://dx.doi.org/10.1039/c0ay00244e 
ESCALONA, V. H. et al. UV-C doses to reduce pathogen and spoilage bacterial growt in vitro and in baby spinach. Postharvest Biology and Technology, v. 56, n. 6, p. 223-231, jun. 2010. http://dx.doi. org/10.1016/j.postharvbio.2010.01.008

FAN, Y. et al. Effect of alginate coating combined with yeast antagonist on strawberry (Fragaria ananassa) preservation quality. Postharvest Biology and Technology, v. 53, p. 84-90, 2009. http://dx.doi. org/10.1016/j.postharvbio.2009.03.002

FRANÇOSO, I. L. T. et al. Alterações físico-químicas em morangos (Fragaria anassa Duch.) irradiados e armazenados. Ciência e Tecnologia de Alimentos, v. 28, n. 3, p. 614-619, jul./set. 2008. http://dx.doi.org/10.1590/S0101-20612008000300017

GANGLIARDI, J. V.; KARNS, J. S. Leaching of Escherichia coli 0157: H7 in diverse soils under various agricultural management practices. Applied and Environmental Microbiology, v. 66, n. 3, p. 877-883, mar. 2000. http://dx.doi.org/10.1128/AEM.66.3.877-883.2000

HAYASHI, T.; TODORIKI, S.; NAGAO, A. Effect of gamma irradiation on the membrane permeability and lipid composition of potato tubers. Environmental and Experimental Botany, v. 32, n. 3, p. 265-271, 1992. http://dx.doi.org/10.1016/0098-8472(92)90009-Q

HAJARE, S. N. et al. Quality profile of litchi (Litchi chinensis) cultivars from India and effect of radiation processing. Radiation Physics and Chemistry, v. 79, n. 9, p. 994-1004, set. 2010. http://dx.doi. org/10.1016/j.radphyschem.2010.03.014

HARDER, M. N. C. et al. Determination of changes induced by gamma radiation in nectar of kiwi fruit (Actinidia deliciosa). Radiation Physics and Chemistry, v. 78, n. 7-8, p. 579-582, jul./ago. 2009.

HUSSAIN, P. R. et al. Gamma irradiation of sun-dried apricots (Prunus armeniaca L.) forquality maintenance and quarantine purposes. Radiation Physics and Chemistry, v. 80, p. 817-827, 2011. http:// dx.doi.org/10.1016/j.radphyschem.2011.02.029

KLUGE, R. A. et al. Fisiologia e manejo pós-colheita de frutas de clima temperado. 2. ed. Campinas: Livraria e Editora Rural, 2002. 214 p.

LAGUNAS-SOLAR, M.C. Radiation processing of foods: An overview of scientific principles and current status. Journal of Food Protection, v. 58, n. 2, p. 186-192, 1995.

LIMA, K. S. C. et al. Cenouras minimamente processadas em embalagens com atmosfera modificadas e tratadas com radiação gama: avaliação microbiológica, físico-química e química. Ciência e Tecnologia de Alimentos, v. 23, n. 2, p. 240-250, maio/ago. 2003.

LÓPEZ-RUBIRA, V. et al. Shelf life and overall quality of minimally processed pomegranate arils modified atmosphere packaged and treated with UV-C. Postharvest Biology and Technology, v. 37, n. 8, p. 174-185, aug. 2005. http://dx.doi.org/10.1016/j. postharvbio.2005.04.003

MARTINS, C. G. et al. Shelf life of irradiated minimally processed (MP) watercress (Nasturtium officinale). Ciência e Tecnologia de Alimentos, v. 27, n. 1, p. 44-48, jan./mar. 2004. http://dx.doi. org/10.1590/S0101-20612007000100008

MAXIE, E. C.; SOMMER, N. F.; MITCHELL, F. G. Chemical, economic, physical and physiological limitations to irradiation of fruit. In: International atomic energy agengy. Disinfestation of fruit by irradiation. Vienna: IAEA, 1971. p. 39-100.

McCREADY, P. M.; McCOMB, E. A. Extration and determination of total pectic material. Analytical Chemistry, v. 24, n. 12, p. 1586-1588, 1952. http://dx.doi.org/10.1021/ac60072a033

MOKADY, S.; COGAN, U.; LIEBERMAN, L. Stability on vitamin C in fruit and fruit blends. Journal Science Food Agricultural, v. 35, p. 452-456, 1984. http://dx.doi.org/10.1002/jsfa.2740350415

OLIVEIRA, A. C. G. et al. Conservação pós-colheita de goiaba branca Kumagai por irradiação gama: aspectos físicos, químicos e sensoriais. Boletim do CEPPA, v. 24, n. 2, p. 375-392, jul./dez. 2006.
ORNELLAS, C. B. D. et al. Atitude do consumidor frente à irradiação de alimentos. Ciência e Tecnologia de Alimentos, v. 26, n. 1, p. 211-213, jan./mar. 2006. http://dx.doi.org/10.1590/S010120612006000100033

PANTELIDIS, G. E. et al. Antioxidants capacity, phenol, anthocyanin and ascorbic acid contents in raspberries, blackberries, red currants, gooseberries and cornelian cherries. Food Chemistry, v. 102, p. 777-783, 2007. http://dx.doi.org/10.1016/j.foodchem.2006.06.021

PEROZZI, M. Irradiação: tecnologia boa para aumentar exportações de frutas. Inovação Uniemp, v. 3, n. 5, p. 42-44, set./out., 2007.

PINTO, D. M. Tecnologias de pós-colheita em caqui 'Fuyu'. 2010. $163 \mathrm{f}$. Tese (Doutorado em Ciência dos Alimentos)-Universidade Federal de Lavras, Lavras, 2010.

PLESSI, M; BERTELLI, D.; ALBASINI, A. Distribution of metals and phenolics compounds as a criterion to evaluate variety of berries and related jams. Food Chemistry, v. 100, p. 419-427, 2007. http:// dx.doi.org/10.1016/j.foodchem.2005.09.018

RASTOGI, N. K. Impact of gamma irradiation 620 on some mass transfer driven operations in food processing. Radiation Physics and Chemistry, v. 73, p. 355-361, 2005. http://dx.doi.org/10.1016/j. radphyschem.2004.11.004

RASTOGI, N. K. et al. Combined effect of gamma irradiation and osmotic pre-treatment on mass transfer during dehydration. Journal of Food Engeneering, v. 77, p. 1059-1063, 2006. http:// dx.doi.org/10.1016/j.jfoodeng.2005.08.035

RESURRECCION, A. V. A. et al. Consumers attitudes towards irradiated food: results of a new study. Journal of Food Protection, v. 58, n. 2, p. 193-196, 1995.

RUFINO, M. D. M. et al. Bioactive compounds and antioxidant capacities of 18 non-traditional tropical fruits from Brazil. Food Chemistry, n. 121, v. 4, p. 996-1002, 2010.

RUFINO, M. S. M. et al. Metodologia científica: determinação da atividade antioxidante total em frutas pela captura do radical livre DPPH. Embrapa Agroindústria Tropical, 2007. 4 p. (Embrapa Agroindústria Tropical. ComunicadoTécnico, n. 127).

SILVA, J. M.; SILVA, J. P.; SPOTO, M. H. F. Características físicoquímicas de abacaxi submetido à tecnologia de radiação ionizante como método de conservação pós-colheita. Ciência e Tecnologia de Alimentos, v. 28, n. 1, p. 139-145, jan./mar. 2008. http://dx.doi. org/10.1590/S0101-20612008000100020

SILVA, N. et al. Manual de Métodos de Análises Microbiológicas de Alimentos. 3. ed. São Paulo: Livraria Varela, 2007. 552 p.

SOUZA, A. R. M. et al. Efeito da radiação gama e do armazenamento na qualidade de pedúnculos de caju (Anacardium occidentale L.). Ciência e Agrotenologia, v. 23, n. 3, p. 848-854, maio/jun. 2009. http://dx.doi.org/10.1590/S1413-70542009000300026

STROHECKER, R.; HENNING, H. M. Analisis de vitaminas: métodos comprobados. Madrid: Paz Montalvo, 1967. 428 p.

TALCOTT, S. T. Chemical components of berry fruits. In: ZHAO, Y. (Ed.). Berry Fruit: value-added products for health promotion. New York: CRC press - Taylor \& Francis Group, 2007. p. 51-72. http:// dx.doi.org/10.1201/9781420006148.ch2

WATERHOUSE, A. L. UNIT I1.1 Determination of Total Phenolics. Current protocols in food analytical chemistry, 2002. Supplement 6. http://dx.doi.org/10.1002/0471142913.faa0101s06

YE, X. Q. et al. Identification of bioactive composition and antioxidant activity in young mandarin fruits. Food Chemistry, v. 124, n. 4, p. 1561-1566, 2011. http://dx.doi.org/10.1016/j. foodchem.2010.08.013 